\title{
Ekonomik Kalkınmada Birleştirici Sosyal Sermaye Üzerine Bir İnceleme
}

\author{
Ümit IZZMEN*
}

öz

"Birleştirici sosyal sermaye" kavramı insanlarla siyasetçiler ve yetkililer arasındaki ilişkilerin doğasını, boyutlarını ve ekonomik etkisini incelemek için uygun bir kavramdır. Bu makalenin amacı politik sistemin içselleştirildiği ekonomik kalkınma çalışmalarında birleştirici sosyal sermaye kavramının öneminin, kavramın gelişiminin ve ekonomik kalkınma çalışmalarına uygulanmasının irdelenerek ortaya konulmasıdır. Kavramın uygunluğu temel teorik katkıların ve Thomson Reuters' Web of Science Core Collection veritabanından seçilen belgelerin derinlemesine analizi yoluyla araştırılmıştır. Analiz, birleştirici sosyal sermaye kavramının ekonomik sonuçları hakkındaki alanının gelişmemiş olduğunu göstermektedir. Birleştirici sosyal sermaye kavramını siyasi kurumlar tarafından şekillendirilen bir kavram olarak ele alan çalışmalar çok azdır. Birleştirici sosyal sermaye kavramının tanımı ve ölçümü konusunda bir mutabakatın olmaması, kavramın imkânlarını sınırlamıştır. Makale, kavramın tanımının Bourdieu tarafından ortaya konulan çizgide netleştirilmesi ve sosyal sermayenin ekonomik etkisini farklı siyasi ortamlarda araştıran çalışmalar yapılması önerisi ile tamamlanmaktadır.

Anahtar Kelimeler: Birleştirici Sosyal Sermaye, Devlet, Ekonomik Kalkınma

JEL Sınıflandırması: A14, O10, Z13

\section{Exploring Linking Social Capital in Economic Development}

\begin{abstract}
Linking social capital is a concept suitable for the study of the nature, extent and economic impact of social interactions with politicians or officials. By reviewing the development of the concept and its application in economic development, this paper aims to gain insight into the usefulness of the concept of linking social capital in economic development studies where political system is internalized. The appropriateness of the concept is reviewed through an in-depth analysis of main theoretical contributions and papers selected from Thomson Reuters' Web of Science Core Collection. Studies that conceptualize linking social capital as shaped by political institutions are rare. Lack of consensus on the definition and measurement of linking social capital limited its usefulness. The paper concludes with a call for clarity in the definition of the concept à la Bourdieu and for further studies that explore the economic impact of social capital under different political environments.
\end{abstract}

Keywords: Linking Social Capital, State, Economic Development

JEL Classification: A14, O10, Z13

Araştırma Makalesi - Geliș Tarihi / Received: 23.11.2018 Kabul Tarihi / Accepted: 09.12.2018

\footnotetext{
* Doç. Dr., Namık Kemal Üniversitesi, İktisadi ve İdari Bilimler Fakültesi, Uluslararası İlişkiler Bölümü, uizmen@nku.edu.tr, ORCID: 0000-0002-6000-1246
} 


\section{INTRODUCTION}

Social relations, networks, norms, and values matter in sustainable development. They enable business and political leaders to act together effectively to pursue shared interests. However, most growth models often overlook how economic actors interact. Growth models that basically include human capital, physical capital and technology can only partially explain growth performance. Growth depends not only on physical and human capital, but also on social interactions between people which is captured by the concept of social capital as well.

Although a somewhat new concept, the concept of social capital has turned into a classical term after the seminal work Making Democracy Work, by Putnam, Leonardi and Nonetti (1993). The concept is now widely used to better understand the interaction between economic performance and societal relations.

The social aspects of economic development have attracted much attention especially in terms of policy challenges that face developing countries. The concept of social capital is a promising concept for handling the interaction between economic and social transformations in developing countries. As Woolcock (1998) suggests, it offers a convenient point of entry for sociopolitical issues into comprehensive multidisciplinary economic issues. Over the past two decades, alongside conventional concepts such as physical capital, human capital and entrepreneurship, the concept of social capital has come into popular use to explain economic development (Doh \& McNeely, 2012).

As the social interactions captured within the social capital concept includes a wide spectrum, after the coining of the term, there were ongoing attempts to make the concept more useful by introducing different forms of it and developing measures for every form. Putnam (1995) introduced a distinction between bonding and bridging social capital and then Woolcock $(1998,2001)$ introduced linking social capital. Since then, there has been a consensus on the three forms of social capital (Woolcock, 2001; OECD, 2001; World Bank 2001; Westlund \& Adam, 2010; Rubin, 2016). Bonding social capital refers to ties within a collectivity; bridging social capital refers to ties between people of different socio-demographic backgrounds and linking social capital refers to ties between the people and the representatives of the institutionalized networks of power and authority.

Since its introduction, the economic consequences of social capital have been widely studied. In investigating the social aspects of economic outcomes at the household, community, regional or national level, the concept of social capital is widely used. However, in this literature the emphasis has always been on the effects of social capital, not on the political framework in which social capital is shaped. Westlund and Adam (2010) makes an extensive survey of this literature. Furthermore, the literature has developed mostly on the bonding and bridging forms of social capital, while linking social capital was neglected. In the literature so far, the functions that should normally be captured by linking social capital are covered mostly by bridging social capital. Consequently, linking social capital has been underestimated and underutilized in the enormous research on social capital in the past two decades.

As Westlund and Adam (2010) showed, a large body of research on the empirics of social capital on economic development lacked clear and statistically significant results. This means that, there is still a scope for the efforts to improve our theoretical understanding and empirical measures of social capital. This can be related to the fact that, generally in the literature, social capital is considered as influencing the political outcome rather than the nature of political institutions framing the formation of social capital. Formulating social capital as endogenous to institutional and political variables and differentiating the formal and informal associations with the help of the concept of linking social capital may improve the understanding of the process. 
The aim of this article is to improve our analytical understanding of the nature and extent of linking social capital on economic outcome by explicitly addressing state-society relations. This study is inspired by Rubin (2016) who undertakes a survey on linking social capital in disaster settings to set forward the dynamics under different political settings and Fine (2001) who criticize the social capital concept as falling short of bringing the social back in to the economic analysis. This article tries to fill the gap in the literature on how linking social capital affects economic outcome under different political settings.

An important problem with respect to immaturity of research on linking social capital may be the lack of clarity of the definition of the concept. If the ties between the people and the government officials and politicians are not explicitly addressed when studying linking social capital, it will not be possible to use the concept as a tool for internalizing political system in economic development analysis. Lack of clarity of the concept, probably results in a variety in unit of analysis. This paper, attempts to increase our understanding on how linking social capital works to improve economic outcome under different political settings by reviewing the existing studies and comparing and analyzing their unit of analysis, definition and measurement, internalization of the political system and country of analysis.

The paper proceeds as follows. The next section describes the methodology used in systematically analyzing the existing studies. Section 3 summarizes the development of the linking social capital concept, prominent theories and recent theoretical developments about the interactions of linking social capital with political framework and economic development. Section 4 provides the findings of the review of the literature. Section 5 discusses the implications of the neglect of political vertical ties in the social capital theory and concludes by highlighting the importance of a balance between different forms of social capital for attaining economic development under a democratic system.

\section{METHODOLOGY}

This paper explores the importance of politics in the linking social capital research by undertaking a critical review of the relevant literature. The literature review was undertaken in two steps. First, the development of the concept of linking social capital and its application in studies of economic development is reviewed in order to clarify how political variables are taken into account in economic development research. This review yields the keywords that are used in the second stage to conduct the survey of the existing literature.

In order to analyze the impact of linking social capital on economic development, the search process was carried on by using the keywords of "economic development", "economic growth", "economic performance", "economic outcome", "welfare" and "well-being". An analysis of the literature on social capital and especially on linking social capital suggests that the keywords of "democracy", "state", "government", "political" and "institutions" can be used to capture how linking social capital functions under different political environments.

The analysis of the existing literature was carried on over selected documents from the Thomson Reuters' Web of Science Core Collection, which is a comprehensive citation database of high quality peer reviewed journals, books and proceedings. The selection process included all types of documents from journals, books, and proceedings, at all times, from all areas but confined to the English language. The search process included the selected keywords either in the title, abstract or keywords of the documents.

As of April 18th, 2018, 65 refereed articles were identified in the Thomson Reuters' Web of Science Core Collection that use the concept of linking social capital together with the abovementioned keywords on political dimension of linking social capital. The number of articles are 
$23^{1}$ for the search with keywords for economic development (see Table A1 on the appendix). A combined search of linking social capital together with the keywords on both the economic development and the political environment returned only nine documents. Although an extended search with "social capital" instead of "linking social capital" together with "economic development" and "political" resulted in 92 articles, since the aim of the study is to increase our analytical understanding of the linking social capital concept, the study was undertaken on the 23 articles that use the linking social capital concept.

The 23 articles were analyzed to address:

1. The extent to which linking social capital is applied in the economic development research;

2. How the concept is defined and measured;

3. In which research areas the concept is applied;

4. What are the analytical methods used;

5. What is the unit of analysis;

6. What is the country for which the research is conducted;

7. Whether the social capital concept is endogenised or only its effects are taken into account

\section{CONCEPTUAL AND THEORETICAL EVOLUTION OF THE CONCEPT OF "LINKING SOCIAL CAPITAL"}

Putnam defines social capital as "... features of social organization such as networks, norms, and social trust that facilitate coordination and cooperation for mutual benefit." (Putnam, 1995, p.67).

After its inception, the concept has evolved to encompass different types of social ties. Today, social capital is understood to have three forms: bonding, bridging and linking. The first two forms of social capital, namely bonding and bridging social capital, were introduced by Putnam (1995). The third was introduced later, by Woolcock (2001), and Szreter and Woolcock (2003).

Bonding social capital refers to trusting and co-operative relations within a homogenous group of people such as family members, close friends, and neighbors, (Woolcock 2001, p. 10). These are horizontal bonds that are often based on kinship and reciprocity. Bridging social capital refers to relations of respect and mutuality between more distant friends, associates, and colleagues. Bridging social capital refers to contacts between people of different sociodemographic backgrounds (nationality, ethnicity, socio-economic status, age, etc.). These ties are expected to broaden people's horizons, help to socialize civic attitudes in general, and serve to break down barriers between different social groups (Scrivens \& Smith 2013, p. 30).

Social capital concept turned to be a tool for bringing the social and political structure into the economic analysis along the lines of linking social capital.

The development of the concept of linking social capital goes back to Fox (1996) and Heller (1996) who argue that, beside the horizontal ties, social capital also has a vertical dimension. Woolcock (2001) has called this vertical dimension as "linkages" (p. 11) and he extended the concept of social capital to cover the social and political environment and to become an encompassing concept.

\footnotetext{
${ }^{1}$ The search returned 2 more articles but an examination those articles yielded that political and economic variables were used out of context. So these two articles were omitted.
} 
The concept of social capital was enlarged further in Grootaert (1998) when he included formalized national structures. "In addition to the largely informal, and often local, horizontal and hierarchical relationships of the first two concepts, this view also includes the more formalized institutional relationships and structures, such as government, the political regime, the rule of law, the court system, and civil and political liberties" (p. 3). Such a wide-ranging conceptualization also opened the way for criticism (examples include Fine, 2001, 2002; Portes, 1998; Solow, 2000; 2002; Arrow, 2000; Haynes, 2009).

The criticism of Fine $(2001,2002)$ is different from the others in that, he argues social capital is not suitable for taking the social and political variables into the economic analysis. Although, Fine's criticisms focuses on bonding and bridging aspects of social capital, whether the introduction of linking social capital overcomes the limitations is a credible question to ask. This study by undertaking a survey of the literature, attempts to offer an answer to this question.

Today, the concept of linking social capital as developed by Woolcock $(1998,2001)$ and Szreter (2002), is understood to capture the hierarchical ties between communities and also the ties between ordinary people and people in positions of influence in formal organizations.

Szreter and Woolcock (2003) define linking social capital as "norms of respect and networks of trusting relationships between people who are interacting across explicit, formal or institutionalized power or authority gradients in society" (p.6). They argue that the horizontal ties acting to 'bridge' individuals that are otherwise more or less equal in terms of their status and power are different from the vertical ties that link people across explicit 'vertical' power differentials, particularly as it pertains to accessing public and private services interaction (p. 6).

This tripartite form of social capital gained popularity after it was adopted by the World Bank (2001) and the OECD (2001). In 2000/2001 World Development Report: Attacking Poverty by the World Bank, linking social capital was seen as capturing an important feature of the poor communities. World Bank defines the linking social capital as the "vertical ties between poor people and people in positions of influence in formal organizations (banks, agricultural extension offices, the police)" and point out that the linking social capital captures the problem of how the poor either is excluded from circles where major decisions on welfare are made (p. 128).Thus the World Bank suggests that it is necessary to distinguish among different dimensions or forms of social capital for understanding and fighting poverty.

\subsection{Linking social capital and its political determinants}

State and society cannot be understood apart from one another. There should be a prominent role for the state-society relations in the social capital discussions, however politics often get relegated to the background (Evans 1996, p. 1127). State-society relations are a necessary part of the social capital theory if not the actual definition (Evans, 1996; Woolcock 1998; Szreter 2002). However, the study of the appropriate political institutions and mechanisms for the creation of social capital is still at its beginning stage.

The social capital literature has evolved along two lines: one which is mainly adopted by neo-classical economists who regard it as mainly a private good and the other one who regard it as a public good. This second line adopted by Evans (1996), Woolcock (1998) and Szreter and Woolcock (2004) assigns a prominent role to the characteristic and extent of the state-society relations when it comes to assess the impact of social capital.

Putnam who follows the first line, adopts a relatively stricter definition of social capital and does not extent the concept beyond associations and civil society to include the nature of the state. For Putnam social capital is the property of individuals gained by the virtue of their membership in social groups. 
In Putnam and Fukuyama's works, civil society is taken to be important for democratic and economic performance of the countries (e.g. Fukuyama 1995, 2001, Putnam 1995) Both writers refer to Tocqueville's visit to the United States in the 1830s when he was impressed by Americans' civic associations. For Tocqueville, Americans were heavily involved in forming associations and this was the device for making democracy work (Tocqueville 1835/1996). Fukuyama underlines the importance of the political function of social capital in a modern democracy and argues that low levels of social capital lead to a number of political dysfunctions (2001).

The mainstream social capital literature has evolved along the lines opened by Putnam by focusing on civic associations. The second avenue which places social capital within the statesociety framework are due to two sociologist, Coleman (1988) and Bourdieu (1986).

Bourdieu (1986) approached social capital as a concept to help explain how the power relations and hierarchies are reproduced in an unequal society. The social capital concept as developed especially by Bourdieu, highlights the importance of the power relations and the nature of the state on shaping the possession and distribution of social capital in the society.

Coleman started to analyze the concept of social capital at almost the same time with Bourdieu (OECD, 2013). For Coleman (1988), social capital can be a useful conceptual tool for introducing social structures into the rational action paradigm that often involves extreme individualistic premises. He gives the example of the study groups of the South Korean radical students as constituting social capital (p. 101)

State-society relations start to affect the research on economic development by utilising the concepts of embeddedness (intra-community ties) and autonomy (extra-community networks) starting with Granovetter (1995) and then by researchers such as Evans (1986) and Woolcock (1998).

Evans (1996) drawing upon the work of researchers including Fox (1996), and Heller (1996) argues that state-society synergy can be a catalyst for development. His analysis of the state-society relations draws upon the concepts of embeddedness (the ties that cross the publicprivate divide) and complementarity. The key constraint is not the initial endowment of social capital at the individual level but the difficulties in scaling up those links upwards to the political level. The weak link may be the character of the state apparatus (Evans, 1996, p. 1125). He argues that linking mobilized citizens to public agencies enhances the efficacy of government. He claims that organized communities with strong public institutions constitute a powerful tool for development (p. 1130).

Woolcock (1998) carries the framework developed by Evans further. He studies the effectiveness of the state and the intensity of social ties with the help of a simple framework that uses embeddedness and autonomy at the micro and macro levels.

Narayan (1999) uses a similar framework and takes the intensity of cross cutting ties and the effectiveness of the state as the horizontal and vertical axis respectively. She discusses the interaction between formal and informal institutions and the role played by the bridging social capital. She gives a useful overview on the nature of the state; and how the state interacts with the distribution of social capital. Although Narayan argues that under good governance conditions state acts as complementing the functions of the informal social groups, she indicates the problems by arguing that when governance deteriorates, those informal social groups substitute the state (1999).

Thanks to the studies of Narayan (1999) and Woolcock (1998), the use of linking social capital concept to create an intermediate step between the state and the poor, turned out to be a powerful argument. That argument opened the way for the state to correct the inequalities. But 
that line of argument didn't go as far to argue that the inequalities are fundamentally rooted in differences of access to material resources and ultimately the product of political and ideological framework, even when there are differential access to power. That limited the concept of linking social capital to be a very critical concept. For Szreter and Woolcock (2004), the definition of social capital per se should not encompass the features of the state. There is an essential role for the state to act as an arbitrator among all the different interest groups in a democratic society (2004, p.7).

The argument that social capital can have both positive and negative economic development effects, dependent on the social ties being inclusive or exclusive has been widely accepted following Portes (1998). Whether social ties are inclusive or exclusive depend on the social and political structures. The dark side of strong bonding capital has been pointed out as the risk of exclusion of minority groups from tightly knit kinship relations (Portes, 1998, 2014). That negative side is also a feature of the linking social capital. Uneven distribution of linking social capital creates problems as various social groups possess different levels of political and social power as social capital concentrates in the hands of the few (Rubin, 2016, p. 443). High degree of density and closure of social relations may indeed bring in costs, although embeddedness in a given network is said to generate many benefits. There is an inherent power asymmetry between social groups, and because of that, social capital may lead to negative as well as positive outcomes. Narayan's (1999) widely quoted sentence that "The same ties that bind also exclude" illustrates the case perfectly (p.5).

Under conditions of high economic inequality, deep social divides and unresponsive state mechanism, spontaneous bridging social capital cannot be expected to develop to connect different socioeconomic groups in the society. In this case, social capital accumulation can be segmented along spatial or ethnic lines (Fox 1995). The negative outcomes such as social exclusion, corruption, cronyism, suppression and even co-option of the state to conflict and violence, can be seen in societies with powerful, tightly knit social groups and lacking accountable administrations (Narayan, 1999; Evans, 1989; World Bank, 1997).

Although social capital as acting to reproduce status quo in socially differentiated societies was expressed by Bourdieu as early as 1986, the concept developed on another route and these problems were not studied in detail in the literature.

As the studies that utilize the linking social capital concept is not widespread, there is no well established way of measuring it. One way of measuring linking social capital is using membership of political parties or formal associations. Rubin (2016) points out that many quantitative studies that analyze linking social capital in disaster contexts use measures of linking social capital of membership of political parties or formal associations, and these can be interpreted as a manifestation of a patron-client system where being part of the so-called network is necessary to extract the needed rents. With respect to membership of political parties, Grootaert (1999) warns that in cases of mandatory membership to local branches of political parties, there is no or only little social capital (p. 6). Furthermore, in cases of mandatory membership to local branches of political parties, linking social capital may work to produce corruption rather than economic benefit to the poor.

Departing from the point that linking social capital is good for economic development, one arrives at the policy implication of building linking social capital among the poor. When a level playing field is nonexistent, the cross cutting ties can only be established through deliberate action. Building linking social capital, is an essential task of the state to bring service to the "socially excluded" (Szreter and Woolcock, 2004). However, the ties established by the state in this case will be different from bridging social capital which develops spontaneously. In principle, there is no guarantee that social capital created as such will lead to a more equitable society (Grooteart, 1998). Indeed, social mechanisms should be in place to protect the social ties 
between powerful institutional actors from turning into corruption, nepotism and exploitation (Woolcock, 1998, p. 163). Thus, it is a challenging task to create efficient bureaucracies that are autonomous from the dominant classes and business elites and also embedded in the society (Woolcock 1998, p. 166).

For policymaking concerns, linking social capital constitutes a useful concept connecting the nature of the political environment to developmental issues. However the literature on linking social capital is not yet sufficiently developed. Long after Woolcock's important article (1998), the challenge is still there: to establish a conducive political environment to generate and balance different types of social capital across the society and creating the conditions for economic development.

\subsection{Linking social capital and its impact on economic development}

Development strategies focus on macroeconomic results without paying much attention to the understanding of the micro-institutional foundations on which they depend (Evans 1996 p.1033). Norms, attitudes, culture, power relations within the society and institutional set-up all blend to shape the exact outcome in economic relations.

The importance of institutions on economic development has been studied since Olson (1982) and North (1990). In the post-1980 era, when the Washington Consensus became a standard model worldwide, the same policy set resulted in different economic outcomes in countries with different institutional environments. This has been the ground on which the social capital literature has flourished. Although social capital as a concept has been in use since the late 1970s, empirical and theoretical advances came in the late 1980s and 1990s (Woolcock, 1998, p. 161).

The link between social capital and economic performance is quite straightforward: trust and civic norms are good for economic development since they reduce transaction costs and disseminate knowledge. Theoretically, economic actors with low levels of social capital face high transaction costs, search and information costs, bargaining costs and decision costs beside problems of coordination, duplication of efforts and more frequent contractual disputes (Doh \& McNeely, 2012, p.827).

Early empirical studies on social capital followed the Putnam et. al. (1993) track and mostly focused on bonding and bridging social capital and how they affect economic performance at different spatial levels. Helliwell and Putnam (1995) showed that in Italy, the regions with more developed civic community had higher growth rates. In the literature that follows, most researchers found that social capital yields measurable economic performance. Most of such studies used variables such as trust and civic norms from the World Values Survey or European Values Survey to measure the impact of bonding and bridging social capital on economic development either at the individual, community, and region or nation levels. Studies that considered the economic impact of linking social capital has to wait for the work of Casey (2004).

The relationship between economic performance and the nature and extent of state-society relations was noticed even in the early studies that did not address it explicitly. The regions of Italy with best institutional performance in the work by Putnam et. al. (1993) being those of left wing local governments, poses the problem of the role of omitted variables (Sabatini, 2008, p. 84). Those omitted variables are related to the institutional and political framework that prepares the ground for social capital to flourish. In that sense, if social capital is endogenous to institutional and political variables, omitting them can lead to serious shortcomings in designing 
a workable development agenda. Formulating social capital as endogenous to institutional and political variables came later with Freitag (2006).

Early empirical studies on the relationship between social capital and economic development, did not deliberately include variables related to linking social capital but tried to capture state-society relations under the heading of bridging social capital. In one of such early studies by Knack and Keefer (1997) concludes that stronger economic performance is associated with trust and civic cooperation but not with associational activity, and that trust and civic cooperation are stronger in countries with formal institutions.

Casey (2004) in his study on the north-south divide in Britain, deliberately included variables related to linking social capital. He used voter turnout, newspaper readership and nonvoting participation as measures of civic engagement to study the relationship between indicators of social capital and economic performance. His findings showed that his variables are largely uncorrelated with economic performance.

Research on social capital has been confined to developed countries; but that has changed when the World Bank launched The Social Capital Initiative. World Bank (1998) defined social capital as referring to the "internal social and cultural coherence of society, the norms and values that govern interactions among people and the institutions in which they are embedded" and acknowledged that "the traditional composition of natural capital, physical or produced capital, and human capital needs to be broadened to include social capital" (p. iii). The variables about institutional capacity and performance of the political system used by this study have been the starting point of the later empirical work on linking social capital. World Bank researchers Narayan and Pritchett (1999a, 1999b) used the World Bank methodology for estimating the effect of social capital on the welfare of household in Tanzania. This study which constitutes an important cornerstone for disseminating the research in developing countries followed by further studies by Woolcock $(1998,2001)$, Sretezer and Woolcock (2004) and Woolcock and Narayan (2000) on both the theoretical framework and empirics of the economic performance outcomes of linking social capital. Since then, the literature on linking social capital has developed on the lines of defining what constitutes linking social capital, how it affects economic performance and how can the government intervenes to improve the outcome.

Woolcock (1998) pointed out the risks of increasing transaction costs and thereby economic exchange when linking social capital as represented by extra-community networks are weak. On the other hand, the situation where linkages are strong but intra-community ties are low, is also harmful for economic development. It results in heightened dissonance between the members of the society and only a modest impact on economic development (p. 172). Woolcock, after examining various combinations of high and low intra-community ties and extra-community networks, reached at the conclusion that to launch economic development initiatives, a community should have social capital in the form of intra-community ties. (p. 1745) But that social capital stock should be combined with extra-community networks, i.e. linkages to non-community members in order to sustain the initiative.

Grootaert and Narayan (2004) in their study on estimating empirically the impact of social capital on household welfare in Bolivia, found that social capital increased household welfare and reduce poverty, and pointed out the complementarity and substitution between formal and informal institutions. They underlined that "history, politics and the existing social and power structures have far-reaching effects on social capital formation" (p. 1179).

The argument that high levels of trust, abiding by norms and laws results in an improvement in social and economic outcomes, justifies a role for the government. However, Grootaert (1999, p.55) emphasized that membership in government sponsored local associations has no measurable effect on the welfare of households, downgrading the proposals for 
government intervention, instead, he suggested establishing a supportive environment for the development of voluntary local associations.

Measuring the effects of the three forms of social capital on economic performance came with Sabatini (2008) almost after a decade of the World Bank's initiative on social capital. Sabatini found that each form of social capital may have a different effect in terms of development and well- being. Linking social capital in Sabatini took two forms: social capital as voluntary organization and social capital as active political participation. He defined linking social capital as ties that create linkages with people in the institutions and developed a measure with a principal component analysis. Beside social participation through voluntary organizations, Sabatini used a fourth dimension that he called social capital as active political participation. His finding suggested that bonding social capital and active political participation are negatively correlated while bridging social capital and linking social capital are positively correlated with well-being (Sabatini 2008, p. 479).

Another strand of the literature applied social capital at regional studies. Iyer et.al. (2005) evaluates the impact of social capital by regions and found a remarkable diversity of the economic and social determinants of social capital in the regions of USA. Later studies had mixed results. A recent survey of that literature by Westlund and Adam (2010) has provided important insights into the diverging results of the empirical studies at different spatial levels. Many studies indicated that bridging social capital favors economic development, instead bonding social capital is somewhat detrimental (Sabatini, 2008; Beugelsdijk and Smulders, 2004). However, most of the studies except Casey (2004), lacked clear and statistically significant results. This means that there is still a scope for the efforts to improve our theoretical understanding and empirical measures of social capital. Formulating social capital as endogenous to institutional and political variables and differentiating the formal and informal associations with the help of the concept of linking social capital, could improve our understanding of the economic development process. The next section, looks at the literature to see where we stand.

\section{WHAT THE SURVEY OF THE LITERATURE ON THE POLITICAL DIMENSIONS OF LINKING SOCIAL CAPITAL USED IN ECONOMIC DEVELOPMENT ANALYSIS TELLS?}

In order to analyze the effect on economic development of linking social capital under different political setups, the literature on the political dimensions of linking social capital used in the analysis of economic development was surveyed. The search process was carried on by using the keywords of "economic development", "economic growth", "economic performance", "economic outcome", "welfare" and "well-being" to capture the analysis of economic development; and the keywords of "democracy", "institution", "state", "government", and "political" were used to capture the political dimension. These keywords in the search process on Thomson Reuters' Web of Science Core Collection yielded 14745 documents for "social capital", 328 documents for "bonding social capital", 391 documents for "bridging social capital" and 147 documents for "linking social capital" as of April 18th, 2018. This finding is in conformity with the findings of Rubin (2016). A survey of the research on social capital by Rubin turns out that most of the studies refers to bonding and bridging social capital whereas linking social capital is least referred (p. 435).

The survey of the literature shows that interest in linking social capital heightened only after 2014. Out of a total of 147 documents, 79 documents were published after 2014. Prior to 2006 there were only 13 documents. Another finding is that, the distribution according to the research areas are varied. However, most of the studies were carried on in areas related with 
public, environmental and occupational health (31) but only 18 of the documents were in the business and economics area. The weight of health related studies is an expected result because the relations established with influential individuals are mostly valuable for the disaster situations.

Most of the documents on 147 linking social capital are articles (131), 8 of them are reviews, 4 are editorial material and 4 are proceedings paper. The following analysis was carried on the articles. Although an equal distribution of linking social capital can be much more problematic in developing countries which score lower in democratization indicators, the majority of the studies were mainly carried on developed countries. 167 OECD countries, but only 32 non-OECD countries appeared in the documents.

In the second step, the survey of the literature was carried on by focusing on the articles that use the concept of linking social capital together with the keywords of "economic development", "economic growth", "economic performance", "economic outcome", "welfare" and "well-being" to capture the analysis of economic development, and the keywords of democracy, institution, state, government and political were used to capture the political dimension. That search resulted in 23 articles.

An in-depth analysis of these 23 articles reveals some interesting results:

There is no consensus on the definition of linking social capital. Similar to the broader concept of social capital (Sabatini, 2006; Scrivens \& Smith, 2013; Engbers et.al, 2017), linking social capital is defined and measured differently and applied to a variety of research areas, with different unit of analysis. The definition and measurement of social capital are elusive; that of the linking social capital are even more so. The studies are usually made for developed countries. Moreover, there is a great diversity in terms of topics, analytical methods used and unit of analysis. This suggests that the literature on the economic impact of linking social capital is at its early stages. As a result of this diversity, findings are also varied. On the basic question of this article, specifically, whether the role of political structures are endogenized or not, bulk of the literature takes political structures as having no impact on the formation of linking social capital.

Although linking social capital is strongly dependent on political institutional structures, negativities such as corruption and nepotism are somehow neglected. The articles that emphasize the potentially adverse effects of linking social capital are rare even for studies where the role of formal institutions are vital such as the disaster situations (Rubin 2016).

Linking social capital is used to analyze the areas such as education, health, environment, urban development and disasters where there is an extensive role for the governmental institutions. Only nine studies are related to the economic development. A closer examination of these nine studies disclose that, some of them are purely theoretical. Szreter and Woolcock (2004) develops a theoretical approach on the political economy of social capital. Rubin (2016) undertakes a meta-study on the political dimension of "linking social capital". In addition, some of them are too specific: Ruiu (2017) explores sustainable agricultural management and Ooi (2015) investigates mountain resort tourism. There are basically two studies with an empirical analysis that can be extended to a broader economic scope. The first one is Sabatini (2008) who performs an empirical analysis on the role of social capital on the quality of economic development. The second one is Casey (2014) who uses linking social capital to study the credit accessibility of the low-wealth entrepreneurs. In order to understand how political institutions shape certain attributes of the social capital that affect the economic outcome, clearly more empirical studies are needed.

The systematic review of the literature suggests that bonding, bridging and linking social capital may lead to outcomes on different directions. This result is similar to the finding that 
studies measuring the impact of the three social capital forms found them to be only weakly interrelated (Sabatini, 2008; Tinarwo, 2015).

In some of the studies there is a scope for public intervention to develop social capital (Bebbington \& Perreault, 1999; Snoxell, Harpham, Grant and Rodriguez, 2006) but with a balanced approach. In fact, if linking social capital is not accompanied by sufficient bonding, and bridging social capital, it can negatively impact democratic governance (Titeca \& Vervisch, 2008) whether there should be a linear progression from bonding to bridging to linking, as suggested by Woolcock (2002), is a subject left unclear. The systematic analysis of the literature carried out here does not support that argument.

\section{DISCUSSION AND CONCLUSION}

The concept of social capital has been likened to the glue that holds societies together (Grootaert and Van Bastealer, 2001). They also argue that there cannot be economic growth or human wellbeing without social capital. After almost two decades, we are quite far from specifying the properties of that glue. In that two decades, there has been a continuous effort to make the concept more operational. Linking social capital constitutes an important step in this direction. However, linking social capital that is the relationships between people interacting across explicit, formal or institutionalized power gradients is the least studied but perhaps the most important form of social capital in terms of developmental outcome.

The research concerning the interactions between social capital and political environment and economic performance is still at its early days. The aspects of political environments are not confined to the political trust and political participation; social interactions under different political regimes can deeply affect the economic outcome. However, most of the research that analyze the impact of social capital with a reference to its political function just focus on political trust and political participation, which reduced the merits of the concept.

15 years after Szreter and Woolcock (2004) have introduced the subject, there is still no consensus on the definition and measurement of linking social capital. The prevailing disagreements are not surprising when one considers that the term is applied in a variety of research areas for both the developed and the developing countries and under different units of analysis. Great variety in terms of unit of analysis, measurement of social capital, methodology, level of economic development, type of political structures used in the analysis when combined with a limited number of research does not allow for making generalizations. Consequently, we have not gone far away on the long-standing question of the role of state in facilitating economic development by way of targeting a more egalitarian distribution of social capital.

Furthermore, the literature review confirms Woolcock's (1998) statement that social capital can justify contradictory public policy measures. The ties established by deliberate public policy measures can strengthen social capital or become instruments of nepotism and corruption.

Many researchers have warned against the downside of social capital (e.g. Portes 1998; Portes 2014). Long before the concept of linking social capital was coined, researchers were well aware of the dark side of bonding social capital that can inherently lead to more exclusive forms of solidarity based on kinship, class, ethnicity, religion, and so on. It was Putnam (1995) who was concerned about the decline in bridging social capital as it bridges underlying social cleavages (p. 665). The observation that "networks and associations consisting of primary social groups without cross-cutting ties lead to the betterment of only those group" has also been a long-standing warning (Narayan 1999) on the state-society dimension of social capital.

Whether there should be a linear progression from bonding to bridging to linking, as suggested by Woolcock (2002), is a subject left unclear. The systematic analysis of the literature 
carried out here does not support that argument. Since Narayan (1999), we know that under conditions of unbalanced development of the three forms of social capital, negative outcomes such as social exclusion, corruption and co-option of the state to conflict and violence can be observed. Previous work came out with a policy advice that what is important is to optimize rather than maximize different types of social capital (Woolcock 1998; Titeca \& Vervisch 2008). The findings of this study underlines the relevance of this policy advice. The proper public policy should aim to turn "linkages with powerful individuals" into "embedded social relations" if those networks are to be resilient against corruption and nepotism.

Social capital is not a magic wand, nor is it a self-contained comprehensive theory (Szreter and Woolcock 2004, p.12). But social capital and especially linking social capital constitute a useful concept for policy makers whose main concern is to improve social and economic outcomes. Linking social capital is a credible point of entry for socio-political issues into the comprehensive problem of economic development and the most important take-away from the literature of linking social capital is to create the conditions for every social group to have equal opportunities for developing links with powerful people.

Fine $(2001,2002)$ who is the most prominent critic of the apolitical character of the social capital concept, argued that"... social capital has studiously ignored questions of power, conflict, the elite and the systemic imperatives of (contemporary) capitalism" (2002, p. 796) and hence "... it can only be rejected not appropriately transformed" (2002, p. 799). The linking social capital, by properly internalizing the political element in social relations could help at offsetting this criticism. On those grounds, a rethinking of the linking social capital concept on the way opened by Bourdieu may enhance its usefulness in understanding the role of the state in facilitating economic development.

The results of this survey suggest that, there is a need for further clarity on the political foundations of linking social capital, like governmental structures, trust in institutions, political participation, voting systems, in developed and developing country settings. Afterward, these findings can be used for measuring the impact of a more egalitarian and balanced social capital distribution on economic development. 
Table A1 Key Attributes of the Linking Social Capital Research of Economic Development ${ }^{2}$

\begin{tabular}{|c|c|c|c|c|c|c|c|c|c|}
\hline & Author & Year & Main topic & Analysis method & $\begin{array}{l}\text { Unit } \\
\text { analysis }\end{array}$ & $\begin{array}{l}\text { Measurement, } \\
\text { definition, } \\
\text { context of } \\
\text { Linking Social } \\
\text { Capital }\end{array}$ & Findings & Country & $\begin{array}{l}\text { Endogeneity } \\
\text { of social } \\
\text { capital }\end{array}$ \\
\hline 1 & $\begin{array}{l}\text { Agger } \\
\text { et.al. }\end{array}$ & 2015 & $\begin{array}{l}\text { Area-based } \\
\text { Initiatives }\end{array}$ & $\begin{array}{l}\text { qualitative } \\
\text { analysis }\end{array}$ & municipalities & $\begin{array}{l}\text { representatives } \\
\text { from formal } \\
\text { institutions of } \\
\text { the state or } \\
\text { business }\end{array}$ & $\begin{array}{l}\text { Area-based } \\
\text { Initiatives } \\
\text { contribute to } \\
\text { creating linking } \\
\text { social capital, } \\
\text { but the extent } \\
\text { of the } \\
\text { contribution } \\
\text { depends on the } \\
\text { level of } \\
\text { bonding and } \\
\text { bridging social } \\
\text { capital in the } \\
\text { area }\end{array}$ & Denmark & $\begin{array}{l}\text { no role of } \\
\text { political } \\
\text { structures on } \\
\text { LSC }\end{array}$ \\
\hline 2 & *Barker & 2015 & $\begin{array}{l}\text { human } \\
\text { service users }\end{array}$ & $\begin{array}{l}\text { qualitative } \\
\text { analysis }\end{array}$ & individual & $\begin{array}{l}\text { ties and } \\
\text { relationships } \\
\text { with } \\
\text { institutions and } \\
\text { people who } \\
\text { occupy a } \\
\text { relative } \\
\text { position of } \\
\text { power; } \\
\text { interactions } \\
\text { with helping } \\
\text { professionals }\end{array}$ & $\begin{array}{l}\text { organizational, } \\
\text { and community } \\
\text { cultures can } \\
\text { affect linking } \\
\text { social capital }\end{array}$ & Australia. & $\begin{array}{l}\text { no role of } \\
\text { political } \\
\text { structures on } \\
\text { LSC }\end{array}$ \\
\hline 3 & *Casey, C & 2014 & $\begin{array}{l}\text { credit } \\
\text { access }\end{array}$ & quantitative & entrepreneurs & $\begin{array}{l}\text { government } \\
\text { organizations, } \\
\text { bank, and } \\
\text { community- } \\
\text { based } \\
\text { organizations }\end{array}$ & $\begin{array}{l}\text { government } \\
\text { support has a } \\
\text { positive effect } \\
\text { for } \\
\text { entrepreneurs }\end{array}$ & $\begin{array}{l}\text { United } \\
\text { States }\end{array}$ & $\begin{array}{l}\text { no role of } \\
\text { political } \\
\text { structures on } \\
\text { LSC }\end{array}$ \\
\hline 4 & Casey, T & 2004 & $\begin{array}{l}\text { economic } \\
\text { performance }\end{array}$ & quantitative & regional & $\begin{array}{l}\text { connections } \\
\text { across groups at } \\
\text { different levels } \\
\text { of the social } \\
\text { hierarchy (i.e. } \\
\text { class); voter } \\
\text { turnout }\end{array}$ & $\begin{array}{lr}\text { only some } \\
\text { elements of } \\
\text { social capital } \\
\text { correlate with } \\
\text { economic } \\
\text { performance }\end{array}$ & Britain & $\begin{array}{l}\text { from politics } \\
\text { to SC; from } \\
\text { SC to } \\
\text { outcome }\end{array}$ \\
\hline 5 & $\begin{array}{l}\text { Cheung, L. } \\
\text { et.al. }\end{array}$ & 2017 & $\begin{array}{l}\text { Social } \\
\text { provisioning } \\
\text { and resource } \\
\text { integration }\end{array}$ & $\begin{array}{lr}\text { empirical } & \text { study } \\
\text { (embedded } & \text { case } \\
\text { study) } & \end{array}$ & $\begin{array}{l}\text { disaster } \\
\text { locations }\end{array}$ & $\begin{array}{l}\text { connections to } \\
\text { external } \\
\text { sources } \\
\text { power of } \\
\text { authority }\end{array}$ & $\begin{array}{l}\text { social } \\
\text { provisioning } \\
\text { strategies } \\
\text { creates three } \\
\text { distinct } \\
\text { network } \\
\text { configurations } \\
\text { based on } \\
\text { different forms } \\
\text { of social capital } \\
\end{array}$ & Australia & $\begin{array}{l}\text { no role of } \\
\text { political } \\
\text { structures on } \\
\text { LSC }\end{array}$ \\
\hline 6 & $\begin{array}{l}\text { Chloupkov } \\
\text { a, J et.al. }\end{array}$ & 2003 & $\begin{array}{l}\text { cooperative } \\
\text { movement }\end{array}$ & case studies & country & $\begin{array}{ll}\text { Trust } & \text { in } \\
\text { institutions } & \end{array}$ & $\begin{array}{l}\text { capitalistic } \\
\text { democracies } \\
\text { are in general } \\
\text { superior to the } \\
\text { communist } \\
\text { dictatorships in } \\
\text { facilitating and } \\
\text { building social } \\
\text { capital. }\end{array}$ & $\begin{array}{l}\text { Denmark } \\
\text { and } \\
\text { Poland }\end{array}$ & $\begin{array}{l}\text { from politics } \\
\text { to SC; from } \\
\text { SC to } \\
\text { outcome }\end{array}$ \\
\hline 7 & $\begin{array}{l}\text { Colistra, } \\
\text { CM }\end{array}$ & 2017 & $\begin{array}{l}\text { health and } \\
\text { well-being }\end{array}$ & $\begin{array}{l}\text { qualitative } \\
\text { phenomenological } \\
\text { approach }\end{array}$ & $\begin{array}{l}\text { community } \\
\text { center }\end{array}$ & $\begin{array}{l}\text { relations among } \\
\text { people who } \\
\text { interact across } \\
\text { explicit, formal, } \\
\text { or } \\
\text { institutionalized } \\
\text { power gradients } \\
\text { in } \\
\text { society } \\
\end{array}$ & $\begin{array}{l}\text { SC established } \\
\text { in the } \\
\text { community } \\
\text { center } \\
\text { contributes to } \\
\text { well-being }\end{array}$ & $\begin{array}{l}\text { United } \\
\text { States }\end{array}$ & $\begin{array}{l}\text { no role of } \\
\text { political } \\
\text { structures on } \\
\text { LSC }\end{array}$ \\
\hline
\end{tabular}

${ }^{2}$ Only nine of these 23 articles use linking social capital and the keywords for economic development and political environment. These articles are marked with an asterics. 


\begin{tabular}{|c|c|c|c|c|c|c|c|c|c|}
\hline 8 & $\begin{array}{l}\text { DaCosta, } \\
\text { E ; Turner, } \\
\text { S }\end{array}$ & 2007 & $\begin{array}{l}\text { natural } \\
\text { disasters. }\end{array}$ & $\begin{array}{l}\text { qualitative } \\
\text { analysis }\end{array}$ & regional & $\begin{array}{l}\text { connects } \\
\text { individuals, } \\
\text { groups or } \\
\text { communities of } \\
\text { different } \\
\text { backgrounds }\end{array}$ & $\begin{array}{l}\text { the creation of } \\
\text { social capital } \\
\text { via State } \\
\text { initiatives has } \\
\text { allowed the } \\
\text { resettled } \\
\text { sampan } \\
\text { dwellers access } \\
\text { to resources }\end{array}$ & Viet Nam & $\begin{array}{l}\text { from politics } \\
\text { to SC; from } \\
\text { SC to } \\
\text { outcome }\end{array}$ \\
\hline 9 & $\begin{array}{l}\text { Daoud, N } \\
\text { et.al. }\end{array}$ & 2016 & $\begin{array}{l}\text { immigrant's } \\
\text { mental } \\
\text { health. }\end{array}$ & $\begin{array}{l}\text { logistic regression } \\
\text { model }\end{array}$ & regional & $\begin{array}{l}\text { engagement in } \\
\text { political } \\
\text { activities }\end{array}$ & $\begin{array}{l}\text { depression } \\
\text { among } \\
\text { immigrants is } \\
\text { differently } \\
\text { impacted by } \\
\text { social capital } \\
\text { types }\end{array}$ & Canada & $\begin{array}{l}\text { no role of } \\
\text { political } \\
\text { structures on } \\
\text { LSC }\end{array}$ \\
\hline 10 & $\begin{array}{l}\text { *Fung, } \\
\text { KK; Hung, } \\
\text { SL }\end{array}$ & 2014 & $\begin{array}{l}\text { community } \\
\text { development }\end{array}$ & qualitative & community & $\begin{array}{l}\text { formal } \\
\text { resources of } \\
\text { information, } \\
\text { services or } \\
\text { funding from } \\
\text { networks with } \\
\text { institutions that } \\
\text { have authority } \\
\text { and decision- } \\
\text { making power }\end{array}$ & $\begin{array}{l}\text { bridging and } \\
\text { linking social } \\
\text { capital is the } \\
\text { most important } \\
\text { form of SC in } \\
\text { serious } \\
\text { deprivation } \\
\text { communities }\end{array}$ & $\begin{array}{l}\text { Hong } \\
\text { Kong }\end{array}$ & $\begin{array}{l}\text { from politics } \\
\text { to SC; from } \\
\text { SC to } \\
\text { outcome }\end{array}$ \\
\hline 11 & $\begin{array}{l}\text { Goulding, } \\
\text { A. }\end{array}$ & 2013 & \begin{tabular}{l}
\multicolumn{2}{c}{ well-being } \\
of the \\
alderly
\end{tabular} & $\begin{array}{ll}\text { focus } & \text { group } \\
\text { interviews } & \end{array}$ & individual & $\begin{array}{l}\text { relationships } \\
\text { between people } \\
\text { from different } \\
\text { social strata }\end{array}$ & $\begin{array}{l}\text { Developing } \\
\text { bonding, } \\
\text { bridging, and } \\
\text { linking social } \\
\text { capital and } \\
\text { cultural capital } \\
\text { through } \\
\text { engagement } \\
\text { with the arts } \\
\text { may have } \\
\text { implications for } \\
\text { health } \\
\end{array}$ & $\begin{array}{l}\text { United } \\
\text { Kingdom }\end{array}$ & $\begin{array}{l}\text { no role of } \\
\text { political } \\
\text { structures on } \\
\text { LSC }\end{array}$ \\
\hline 12 & $\begin{array}{l}\text { Holland, } \\
\text { DS et.al. }\end{array}$ & 2015 & $\begin{array}{l}\text { harvest } \\
\text { cooperatives }\end{array}$ & quantitative & industries & $\begin{array}{l}\text { involvement } \\
\text { with the } \\
\text { management of } \\
\text { the fishery }\end{array}$ & $\begin{array}{l}\text { Profitability is } \\
\text { associated with } \\
\text { broader } \\
\text { community and } \\
\text { fishery-wide } \\
\text { connections as } \\
\text { well as bonding } \\
\text { social capital } \\
\text { within sectors }\end{array}$ & $\begin{array}{l}\text { UNITED- } \\
\text { STATES }\end{array}$ & $\begin{array}{l}\text { no role of } \\
\text { political } \\
\text { structures on } \\
\text { LSC }\end{array}$ \\
\hline 13 & $\begin{array}{l}\text { Holland, } \\
\text { DS et.al. }\end{array}$ & 2013 & $\begin{array}{l}\text { harvest } \\
\text { cooperatives }\end{array}$ & quantitative & industries & $\begin{array}{ll}\text { relationships } & \\
\text { with } & \\
\text { individuals } & \text { in } \\
\text { positions } & \text { of } \\
\text { influence } & \text { or } \\
\text { power } & \\
\end{array}$ & $\begin{array}{l}\text { social capital } \\
\text { can play an } \\
\text { important role } \\
\text { in determining } \\
\text { overall fishery } \\
\text { performance }\end{array}$ & $\begin{array}{l}\text { UNITED- } \\
\text { STATES }\end{array}$ & $\begin{array}{l}\text { no role of } \\
\text { political } \\
\text { structures on } \\
\text { LSC }\end{array}$ \\
\hline 14 & $\begin{array}{l}\text { Mason, } \\
\text { DM }\end{array}$ & 2016 & $\begin{array}{l}\text { healthcare } \\
\text { access of } \\
\text { irregular } \\
\text { migrants }\end{array}$ & qualitative & individual & $\begin{array}{l}\text { a vertical } \\
\text { strategy to } \\
\text { provide access } \\
\text { to services or } \\
\text { relationships } \\
\text { who lack social } \\
\text { capital }\end{array}$ & $\begin{array}{lr}\text { LSC } & \text { can } \\
\text { improve access } \\
\text { and healthcare } \\
\text { outcomes for } \\
\text { both } \\
\text { irregular the } \\
\text { migrant } \\
\end{array}$ & Spain & $\begin{array}{l}\text { no role of } \\
\text { political } \\
\text { structures on } \\
\text { LSC }\end{array}$ \\
\hline 15 & $\begin{array}{ll}\text { *Ooi, } & \mathrm{N} \\
\text { et.al. } & \end{array}$ & 2015 & $\begin{array}{l}\text { sustainable } \\
\text { tourism }\end{array}$ & $\begin{array}{l}\text { ethnographic case } \\
\text { study }\end{array}$ & community & $\begin{array}{l}\text { vertical } \\
\text { bridging of } \\
\text { resources and } \\
\text { power across } \\
\text { different levels } \\
\text { of society and } \\
\text { influence }\end{array}$ & $\begin{array}{l}\text { complex and } \\
\text { inter-connected } \\
\text { relationship, } \\
\text { with particular } \\
\text { social capital } \\
\text { outcomes }\end{array}$ & US & $\begin{array}{l}\text { no role of } \\
\text { political } \\
\text { structures on } \\
\text { LSC }\end{array}$ \\
\hline 16 & $\begin{array}{l}\text { Raymond- } \\
\text { Flesch, M } \\
\text { et.al. }\end{array}$ & 2017 & $\begin{array}{l}\text { adolescent } \\
\text { wellbeing }\end{array}$ & focus groups & individual & $\begin{array}{l}\text { networks of } \\
\text { trusting and } \\
\text { respectful } \\
\text { relationships } \\
\text { between people } \\
\text { who are acting } \\
\text { across explicit } \\
\text { power or } \\
\text { authority } \\
\text { gradients; } \\
\text { capacities to } \\
\text { link them to } \\
\text { structural } \\
\end{array}$ & $\begin{array}{lr}\text { Limited } & \\
\text { bridging } & \text { and } \\
\text { linking } & \text { SC } \\
\text { negative } & \text { on } \\
\text { health } & \text { and } \\
\text { upward } & \text { social } \\
\text { mobility } & \end{array}$ & US & $\begin{array}{l}\text { no role of } \\
\text { political } \\
\text { structures on } \\
\text { LSC }\end{array}$ \\
\hline
\end{tabular}


resources

\begin{tabular}{|c|c|c|c|c|c|c|c|c|c|}
\hline 17 & $*$ Rubin, $\mathrm{O}$ & 2016 & $\begin{array}{l}\text { disaster } \\
\text { settings. }\end{array}$ & meta-study & - & $\begin{array}{l}\text { expressions of } \\
\text { organizational } \\
\text { trust and } \\
\text { participation }\end{array}$ & $\begin{array}{l}\text { potential risks } \\
\text { inherent in the } \\
\text { relationships } \\
\text { between local } \\
\text { authorities and } \\
\text { communities in } \\
\text { disaster } \\
\text { settings. }\end{array}$ & - & $\begin{array}{l}\text { from politics } \\
\text { to SC; from } \\
\text { SC to } \\
\text { outcome }\end{array}$ \\
\hline 18 & Rubin, $\mathrm{O}$ & 2017 & $\begin{array}{l}\text { disaster } \\
\text { settings. }\end{array}$ & $\begin{array}{l}\text { quantitative and } \\
\text { qualitative }\end{array}$ & - & $\begin{array}{ll}\text { social relations } \\
\text { that link } & \text { to } \\
\text { people } & \text { in } \\
\text { positions } & \text { of } \\
\text { influence } & \text { in } \\
\text { formal } & \\
\text { organizations }\end{array}$ & $\begin{array}{l}\text { The linkages } \\
\text { between the } \\
\text { communities } \\
\text { and local } \\
\text { authorities } \\
\text { appear to be } \\
\text { susceptible to } \\
\text { social inertia } \\
\text { during times of } \\
\text { stress }\end{array}$ & Vietnam & $\begin{array}{l}\text { from politics } \\
\text { to SC; from } \\
\text { SC to } \\
\text { outcome }\end{array}$ \\
\hline 19 & $\begin{array}{l}\text { Ruiu, ML } \\
\text { et.al. }\end{array}$ & 2017 & $\begin{array}{l}\text { sustainable } \\
\text { agriculture }\end{array}$ & $\begin{array}{l}\text { qualitative } \\
\text { analysis }\end{array}$ & district & institutional ties & $\begin{array}{l}\text { social capital } \\
\text { contributes } \\
\text { towards } \\
\text { increasing } \\
\text { resilience }\end{array}$ & $\begin{array}{l}\text { Italy } \\
\end{array}$ & $\begin{array}{l}\text { from politics } \\
\text { to SC; from } \\
\text { SC to } \\
\text { outcome }\end{array}$ \\
\hline 20 & $\begin{array}{l}\text { *Sabatini, } \\
\text { F }\end{array}$ & 2008 & $\begin{array}{l}\text { economic } \\
\text { development }\end{array}$ & $\begin{array}{l}\text { multivariate } \\
\text { analysis and of a } \\
\text { structural } \\
\text { equations models }\end{array}$ & regional & $\begin{array}{l}\text { ties that } \\
\text { connect people } \\
\text { coming from } \\
\text { diverse socio- } \\
\text { economic } \\
\text { backgrounds } \\
\text { and create } \\
\text { linkages with } \\
\text { people in the } \\
\text { institutions; } \\
\text { active political } \\
\text { participation }\end{array}$ & $\begin{array}{l}\text { LSC positively } \\
\text { associated with } \\
\text { human } \\
\text { development }\end{array}$ & Italy & $\begin{array}{l}\text { no role of } \\
\text { political } \\
\text { structures on } \\
\text { LSC }\end{array}$ \\
\hline 21 & $\begin{array}{l}\text { *Sundquist } \\
\text {, J et.al. }\end{array}$ & 2006 & $\begin{array}{l}\text { coronary } \\
\text { heart disease }\end{array}$ & cohort study & Neighbourhood & $\begin{array}{l}\text { proportions of } \\
\text { individuals } \\
\text { voting in local } \\
\text { government } \\
\text { elections }\end{array}$ & $\begin{array}{l}\text { individual } \\
\text { health is } \\
\text { affected by } \\
\text { differences } \\
\text { between } \\
\text { neighbourhoods } \\
\text { in linking social } \\
\text { capital. } \\
\end{array}$ & Sweden & $\begin{array}{l}\text { from politics } \\
\text { to SC; from } \\
\text { SC to } \\
\text { outcome }\end{array}$ \\
\hline 22 & $\begin{array}{l}\text { *Szreter, } \\
\text { S; } \\
\text { Woolcock, } \\
\text { M }\end{array}$ & 2003 & $\begin{array}{l}\text { public } \\
\text { health }\end{array}$ & conceptual & - & $\begin{array}{lr}\text { as norms } & \text { of } \\
\text { respect } & \text { and } \\
\text { networks } & \text { of } \\
\text { trusting } & \\
\text { relationships } & \end{array}$ & $\begin{array}{l}\text { a distinction } \\
\text { between } \\
\text { bonding, } \\
\text { bridging, and } \\
\text { linking social } \\
\text { capital offers a } \\
\text { better } \\
\text { framework }\end{array}$ & - & $\begin{array}{l}\text { from politics } \\
\text { to SC; from } \\
\text { SC to } \\
\text { outcome }\end{array}$ \\
\hline 23 & $\begin{array}{l}\text { Urwin, } \quad P \\
\text { et.al. }\end{array}$ & 2008 & job search & $\begin{array}{l}\text { ordered probit, } \\
\text { OLS }\end{array}$ & individual & $\begin{array}{l}\text { linking capital } \\
\text { exists between } \\
\text { an individual } \\
\text { and a group or } \\
\text { organization }\end{array}$ & $\begin{array}{l}\text { any returns to } \\
\text { investment in } \\
\text { linking social } \\
\text { capital simply } \\
\text { derive from the } \\
\text { positive signals } \\
\text { that group } \\
\text { membership } \\
\text { may transmit to } \\
\text { potential } \\
\text { employers }\end{array}$ & Britain & $\begin{array}{l}\text { no role of } \\
\text { political } \\
\text { structures on } \\
\text { LSC }\end{array}$ \\
\hline
\end{tabular}




\section{REFERENCES}

(The references marked with an asterisk indicate studies included in the literature analysis)

Arrow, K. J. (2000). Observations on social capital. In Dasgupta, P., \& Serageldin, I. (Ed.), Social capital : A multifaceted perspective. (pp. 3-5). World Bank Publications. Washington, D.C. doi:10.1596/0-8213-4562-1

*Agger, A., \& Jensen, J. O. (2015). Area-based initiatives-and their work in bonding, bridging and linking social capital. European Planning Studies, 23(10), 2045-2061. doi:10.1080/09654313.2014.998172

*Barker, J., \& Thomson, L. (2015). Helpful relationships with service users: Linking social capital. Australian Social Work, 68(1), 130-145. doi:10.1080/0312407X.2014.905795

Bebbington, A., \& Perreault, T. (1999). Social capital, development, and access to resources in highland Ecuador. Economic Geography, 75(4), 395-418. doi:10.2307/144478

Beugelsdijk, S. \& Smulders, S. (2003). Social capital and economic growth, Tilburg University, Department of Economics. Retrieved from http://www.dur.ac.uk/economics.guestspeakers/2003_04/Smulders.pdf .

Bourdieu, P. (1986). The forms of capital. In Richardson, J. (Ed.), Theory and Research in the Sociology of Education, Greenwood Press, New York, NY, pp. 241-58.

*Casey, C. (2014). Critical connections: The importance of community-based organizations and social capital to credit access for low-wealth entrepreneurs. Urban Affairs Review, 50(3), 366-390. doi:10.1177/1078087413508915

*Casey, T. (2004). Social capital and regional economies in Britain. Political Studies, 52(1), 96-117. doi: 10.1111/j.1467-9248.2004.00466.x

*Cheung, L., McColl-Kennedy, J. R., \& Coote, L. V. (2017). Consumer-citizens mobilizing social capital following a natural disaster: Effects on well-being. Journal of Services Marketing, 31(4/5), 438-451. doi:10.1108/JSM-05-20160192

*Chloupkova, J., Svendsen, G. L. H., \& Svendsen, G. T. (2003). Building and destroying social capital: The case of cooperative movements in denmark and poland. Agriculture and Human Values, 20(3), 241-252. doi:10.1023/A:1026141807305

Coleman, J. (1988). Social capital in the creation of human capital. American Journal of Sociology, 94, S95-S120. Retrieved from http://www.jstor.org/stable/2780243

*Colistra, C. M., Schmalz, D., \& Glover, T. (2017). The meaning of relationship building in the context of the community center and its implications. Journal of Park and Recreation Administration, 35(2)

*DaCosta, E., \& Turner, S. (2007). Negotiating changing livelihoods: The sampan dwellers of tam giang lagoon, việt nam. Geoforum, 38(1), 190-206. doi:10.1016/j.geoforum.2006.08.003

*Daoud, N., Haque, N., Gao, M., Nisenbaum, R., Muntaner, C., \& O'Campo, P. (2016). Neighborhood settings, types of social capital and depression among immigrants in toronto. Social Psychiatry and Psychiatric Epidemiology, 51(4), 529-538. doi:10.1007/s00127-016-1173-z

Doh, S. \& McNeely, C.L. (2012). A multi-dimensional perspective on social capital and economic development: an exploratory analysis. Annals of Regional Science. 49: 821. https://doi.org/10.1007/s00168-011-0449-1

Durlauf, S. N. (2002). On the empirics of social capital. The Economic Journal, 112(483), F459-F479. doi:10.1111/1468-0297.00079

Engbers, T. A., Thompson, M. F., \& Slaper, T. F. (2017). Theory and measurement in social capital research. Social Indicators Research, 132(2), 1-22. doi:10.1007/s11205-016-1299-0

Evans, P. (1996). Government action, social capital and development: Reviewing the evidence on synergy. World Development, 24(6), 1119-1132. doi:10.1016/0305-750X(96)00021-6

Fine, B. (2001). Social Capital versus Social Theory. London: Routledge

Fine, B. (2002). They $f^{* * k}$ you up those social capitalists. Antipode, 34(4), 796-799. doi: 10.1111/1467-8330.00271

Fox, J. (1996). How does civil society thicken? The political construction of social capital in rural Mexico. World Development, 24(6), 1089-1103. doi:10.1016/0305-750X(96)00025-3

Freitag, M. (2006). Bowling the state back in: Political institutions and the creation of social capital. European Journal of Political Research, 45(1), 123-152. doi:10.1111/j.1475-6765.2005.00293.x

Fukuyama, F. (2001). Social capital, civil society and development. Third World Quarterly, 22(1), 7-20. doi:10.1080/713701144 
Fukuyama, F. (1995). Trust: The Social Virtues and the Creation of Prosperity Free Press New York, NY.

*Fung, KK \& Hung, SL. (2014). Strengthening a community of poverty in an affluent society: strategies to build social capital in Tin Shui Wai North in Hong Kong, Community Development Journal, 49(3), 441-457. doi:10.1093/cdj/bst051

*Goulding, A. (2013). How Can Contemporary Art Contribute Toward the Development of Social and Cultural Capital for People Aged 64 and Older. Gerontologist, 53(6) 1009-1019 doi:10.1093/geront/gns 144

Granovetter, M. S. (1985). Economic action and social structure: The problem of embeddedness. American Journal of Sociology, 91. 481-510. 10.1086/228311.

Grootaert, C. (1998). Social capital: the missing link? Social Capital Initiative Working Paper Series; no. 3. The World Bank, Washington, D.C. Rrom: http://documents.worldbank.org/curated/en/902971468764409654/Social-capital-the-missing-link

Grootaert, C. (1999). Social capital, household welfare, and poverty in Indonesia. Policy, Research Working Papers; no. WPS 2148. World Bank, Washington, DC. Retrieved from: http://documents.worldbank.org/curated/en/738431468751146917/Social-capital-houshold-welfare-and-poverty-inIndonesi

Grootaert, C., \& Narayan, D. (2004). Local institutions, poverty and household welfare in Bolivia. World Development, 32(7), 1179-1198. doi:10.1016/j.worlddev.2004.02.001

Grootaert, C., \& Van Bastelaer, T. (2001). Understanding and measuring social capital: a synthesis of findings and recommendations from the social capital initiative World Bank, Washington, DC, Retrieved from: http://siteresources.worldbank.org/INTSOCIALCAPITAL/Resources/Social-Capital-Initiative-Working-PaperSeries/SCI-WPS-24.pdf

Haynes, P. (2009). Before going any further with social capital: Eight key criticisms to address. Ingenio (CSIC-UPV) Working Paper Series, 2009/2. Retrieved from: http://www.ingenio.upv.es/sites/default/files/workingpaper/before_going_any_further_with_social_capital_eight_key_criticisms_to_address.pdf

Heller, P. (1996). Social capital as a product of class mobilization and state intervention: Industrial workers in Kerala, India. World Development, 24(6), 1055-1071. doi:10.1016/0305-750X(96)00015-0

Helliwell, J. F., \& Putnam, R. D. (1995). Economic growth and social capital in Italy. Eastern Economic Journal, 21(3), 295-307. Retrieved from: https://www.jstor.org/stable/pdf/40325643.pdf?refreqid=excelsior\%3A48221fd5e75cb96b590c6426d6f82adb

*Holland, D. S., Kitts, A. W., Patricia Pinto da Silva, \& Wiersma, J. (2013). Social capital and the success of harvest cooperatives in the New England groundfish fishery. Marine Resource Economics, 28(2), 133-153. doi:10.5950/0738$1360-28.2 .133$

*Holland, D. S., Patricia Pinto da Silva, \& Kitts, A. W. (2015). Evolution of social capital and economic performance in new england harvest cooperatives. Marine Resource Economics, 30(4), 371-392. doi:10.1086/682153

Iyer, S., Kitson, M., \& Toh, B. (2005). Social capital, economic growth and regional development. Regional Studies, 39(8), 1015-1040. doi:10.1080/00343400500327943

Knack, S., \& Keefer, P. (1997). Does social capital have an economic payoff? A cross-country investigation. The Quarterly Journal of Economics, 112(4), 1251-1288. doi:10.1162/003355300555475

*Mason, D. M. (2016). Caring for the unseen: Using linking social capital to improve healthcare access to irregular migrants in Spain: Caring for the unseen. Journal of Nursing Scholarship, 48(5), 448-455. doi:10.1111/jnu.12228

Narayan, D. (1999). Bonds and bridges: social and poverty (English). Policy, Research working paper; no. WPS 2167. Washington, DC: World Bank. http://documents.worldbank.org/curated/en/989601468766526606/Bonds-andbridges-social-and-poverty

Narayan, D., \& Pritchett, L. (1999a). Social capital: Evidence and implications. In Dasgupta, P. \& Serageldin, I. (Ed). Social capital: A multifaceted perspective. (pp. 269-295). Washington: World Bank Publications. doi:10.1596/0-82134562-1

Narayan, D., \& Pritchett, L. (1999b). Cents and sociability: Household income and social capital in rural Tanzania. Economic Development and Cultural Change, 47(4), 871-897. doi:10.1086/452436

North, Douglass (1990) Institutions, institutional change, and economic performance. Cambridge University Press, New York, NY.

OECD (2001). The well-being of nations: the role of human and social capital. OECD, Paris. 
Olson, M. (1982) The Rise and Decline of Nations. Yale University Press, New Haven.

*Ooi, N., Laing, J., \& Mair, J. (2015). Social capital as a heuristic device to explore sociocultural sustainability: A case study of mountain resort tourism in the community of steamboat springs, Colorado, USA. Journal of Sustainable Tourism, 23(3), 417-436. doi:10.1080/09669582.2014.957211

Portes, A. (1998). Social capital: Its origins and applications in modern sociology. Annual Review of Sociology, 24(1), 1-24. doi:10.1146/annurev.soc.24.1.1

Portes, A. (2014). Downsides of social capital. Proceedings of the National Academy of Sciences of the United States of America, 111(52), 18407-18408. doi:10.1073/pnas.1421888112

Putnam, R. (1995). Tuning in, tuning out: the strange disappearance of social capital in America. PS: Political Science and Politics, 28(4), 664-683. doi:10.2307/420517

Putnam, R., Leonardi, R., \& Nonetti, R. (1993). Making democracy work: Civic traditions in modern Italy. Princeton University Press. Retrieved from http://www.jstor.org/stable/j.ctt7s8r7

*Raymond-Flesch, M., Auerswald, C., McGlone, L., Comfort, M., \& Minnis, A. (2017). Building social capital to promote adolescent wellbeing: A qualitative study with teens in a Latino agricultural community. BMC Public Health, 17(1), 1-9. doi:10.1186/s12889-017-4110-5

*Rubin, O. (2015). The burden of excessive "linking social capital" evidence from four Vietnamese provinces. Asian Journal of Social Science, 43(6), 760-785. doi: 10.1163/15685314-04306006

*Rubin, O. (2016). The political dimension of "linking social capital": Current analytical practices and the case for recalibration. Theory and Society, 45(5), 429-449. doi:10.1007/s11186-016-9277-8

*Ruiu, M. L., Seddaiu, G., \& Roggero, P. P. (2017). Developing adaptive responses to contextual changes for sustainable agricultural management: The role of social capital in the Arborea district (Sardinia, Italy). Journal of Rural Studies, 49, 162-170. doi:10.1016/j.jrurstud.2016.11.017

*Sabatini, F. (2008). Social capital and the quality of economic development. Kyklos, 61(3), 466-499. doi:10.1111/j.1467-6435.2008.00413.x

Scrivens, K. and C. Smith (2013). Four interpretations of social capital: an agenda for measurement, OECD Statistics Working Papers, 2013/06, OECD Publishing. http://dx.doi.org/10.1787/5jzbcx010wmt-en

Snoxell, S., Harpham, T., Grant, E., \& Rodriguez, C. (2016). Social capital interventions: A case study from Cali, Colombia. Canadian Journal of Development Studies/Revue Canadienne d'Études Du Développement, 27(1), 65-81. doi:10.1080/02255189.2006.9669121

Solow, R. M. (2000). Notes on social capital and economic performance. In Dasgupta, P., \& Serageldin, I. (Ed). Social capital: A multifaceted perspective. (p. 6-10). World Bank Publications. Washington, D.C. doi:10.1596/0-82134562-1

*Sundquist, J., Sundquist, K., Johansson, S., \& Yang, M. (2006). Low linking social capital as a predictor of coronary heart disease in Sweden: A cohort study of 2.8 million people. Social Science \& Medicine, 62(4), 954-963. doi:10.1016/j.socscimed.2005.06.049

Szreter, S. (2002). The state of social capital: Bringing back in power, politics, and history. Theory and Society, 31(5), 573-621. doi:10.1023/A:1021300217590

*Szreter, S., \& Woolcock, M. (2003). Health by association? Social capital, social theory, and the political economy of public health. International Journal of Epidemiology, 33, 650-667. 10.1093/ije/dyh013.

Tinarwo, M. T. (2015). Forging ties: Social capital utilization by Zimbabwean social workers in Britain. Journal of International Migration and Integration, 16(4), 851-869. doi:10.1007/s12134-014-0356-2

Titeca, K., \& Vervisch, T. (2008). The dynamics of social capital and community associations in Uganda: Linking capital and its consequences. World Development, 36(11), 2205-2222. doi:10.1016/j.worlddev.2007.10.021

Tocqueville, A. (2003). Democracy in America. Henry Reeve (Trans.), Btuce Frohnen(Ed.). Regnery Publishing. Washington, D.C.

*Urwin, P., DiPietro, G., Sturgis, P., \& Jack, G. (2008). Measuring the returns to networking and the accumulation of social capital: Any evidence of bonding, bridging, or linking? The American Journal of Economics and Sociology, 67(5), 941-968. doi:10.1111/j.1536-7150.2008.00603.x

Westlund, H., \& Adam, F. (2010). Social capital and economic performance: A meta-analysis of 65 studies. European planning studies, 18(6), 893-919. doi:10.1080/09654311003701431 
Woolcock, M. (1998). Social capital and economic development: Toward a theoretical synthesis and policy framework. Theory and Society, 27(2), 151-208. doi:10.1023/A:1006884930135

Woolcock, M. (2001). The place of social capital in understanding social and economic outcomes. Canadian journal of policy research, 2(1), 11-17.

Woolcock, M., \& Narayan, D. (2000). Social capital: Implications for development theory, research, and policy. The World Bank Research Observer, 15(2), 225-249. doi:10.1093/wbro/15.2.225

World Bank (1998). The initiative on defining, monitoring and measuring social capital: Overview and program description. Social Capital Initiative Working Paper No. 1 Retrieved from http://siteresources.worldbank.org/INTSOCIALCAPITAL/Resources/Social-Capital-Initiative-Working-PaperSeries/SCI-WPS-01.pdf

World Bank (1997). World Development Report 1997: The State in a Changing World. Oxford University Press, New York, NY. Retrieved from https://openknowledge.worldbank.org/handle/10986/5980 License: CC BY 3.0 IGO.”

World Bank (2001). World Development Report2000/2001: Attacking Poverty. Oxford University Press, New York, NY. Retrieved from https://openknowledge.worldbank.org/handle/10986/11856 License: CC BY 3.0 IGO." 